\title{
Pensando o Dia Mundial da Depressão com Ações Humanizadas: a Escuta e o Fazer como Processo de Acolhimento. Relato de Experiência.
}

\author{
Leite, Isabel Alonso; Piva, Denise Regina; Cardoso, Eliana Souza; Brandão, \\ Mariana Haron; Moraes, Natália Cristina \\ Centro de Referência do Idoso da Zona Norte de São Paulo — denise.piva@uol.com.br
}

Introdução: Considerando a implantação da Política Nacional de Humanização (PNH) em 2003 tem-se apontado a importância da revisão do atendimento oferecido em serviços de saúde. uma forma de propor ações humanizadas é buscar a aproximação dos profissionais da saúde com as necessidades do usuário. o presente resumo descreverá uma ação humanizada realizada em um ambulatório especializado em atenção ao idoso da zona norte de São Paulo durante o Dia Mundial da Depressão. Conforme dados da Organização Mundial de Saúde (OMS), pessoas com mais de 65 anos de idade corresponderão a $10 \%$ da população mundial em 25 anos e estudos epidemiológicos têm mostrado que $15 \%$ delas apresentarão sintomas depressivos. Os fatores que podem contribuir para os quadros depressivos podem envolver problemas familiares, luto, desemprego, frustrações, abandono, adversidades físicas, entre outros. Objetivos: Através de uma ação humanizada focada na necessidade do usuário, o evento teve como objetivo sensibilizar e orientar os idosos e a comunidade sobre o tema da depressão, além de incentivá-los a buscar ajuda especializada para tratamento. Método: a organização do "Dia da Depressão" aberto aos idosos, comunidade e colaboradores do serviço ambulatorial, contou com uma palestra com a temática "depressão e envelhecimento". em um segundo momento, foi aberto o ciclo das seguintes oficinas participativas: Musicoterapia onde através da sonoridade, o participante foi convidado a experienciar a possibilidade de sentir alegria, tranquilidade e sensação de bem-estar; Dança Sênior possibilitou ao participante através da música e do movimento, novas maneiras de olhar e interagir com o próprio corpo; Mandalas como recurso para possibilitar o autoconhecimento através de trabalho criativo; lluminando o envelhecer no qual a história biográfica do participante foi usada como processo de reflexão afim de dar novos significados aos fatos vividos, descobrindo também novos caminhos e alternativas para futuras ações. Posteriormente foi oferecido um espaço para discussão da temática através da exibição de um filme. Resultados: Cerca de 120 pessoas participaram do evento. Notouse a motivação dos usuários para refletir e discutir sobre a Depressão, tanto por meio de experiências pessoais como através de breve conhecimento sobre a doença. Conclusão: Ações que proponham a participação ativa do usuário de saúde viabilizam o surgimento de discussão, reflexões e esclarecimentos sobre diversos temas de forma a sensibilizar a comunidade tanto para a busca de ajuda especializada quanto para o autocuidado. a humanização, neste sentido, tende a aproximar os profissionais de saúde às reais necessidades da população atendida, oferecendo a escuta e acolhimento das necessidades apresentadas.

Leite, Isabel Alonso; Piva, Denise Regina; Cardoso, Eliana Souza; Brandão, Mariana Haron; Moraes, Natália Cristina. Pensando o Dia Mundial da Depressão com Ações Humanizadas: a Escuta e o Fazer como Processo de Acolhimento. Relato de Experiência.. In: Anais do Congresso Internacional de Humanidades \& Humanização em Saúde [= Blucher Medical Proceedings, num.2, vol.1]. São Paulo: Editora Blucher, 2014. ISSN 2357-7282

DOI 10.5151/medpro-cihhs-10392 